\title{
The contribution of self control to students' discipline
}

\author{
Soeci Izzati Adlya ${ }^{1}$, A. Muri Yusuf ${ }^{1}$, Z. Mawardi Effendi ${ }^{1}$ \\ ${ }^{1}$ Universitas Negeri Padang, Indonesia
}

\begin{tabular}{l}
\hline \hline Article Info \\
\hline Article history: \\
Received Jan $15^{\text {th }}, 2020$ \\
Revised Feb $21^{\text {st }}, 2020$ \\
Accepted Mar $19^{\text {th }}, 2020$ \\
\end{tabular}

Keyword:

Discipline

Self control

\begin{abstract}
Good self control will lead individual to have discipline behavior. This research aims to describe the contribution of self control to students' discipline. This research used a quantitative approach with a descriptive method. The subject of the research was 275 students. Scale was used to collect the data which consist of Self Control Scale and Students' Discipline Scale. The data was analyzed by using descriptive statistic method and simple regression with SPSS version 20. The research findings shows significant contribution of self control to students' discipline. Thus, self control gives significant impact to students' discipline. This findings is based on data analysis which shows $r$ score 0,590 means there is strong relationship between self control and students' discipline.
\end{abstract}

(C) 2020 The Authors. Published by Redwhitepress

This is an open access article under the CC BY-NC-SA license (https://creativecommons.org/licenses/by-nc-sa/4.0/

\section{Corresponding Author:}

Soeci Izzati Adlya,

Universitas Negeri Padang

Email: soeci.izzati@gmail.com

\section{Introduction}

Behavior is an important aspect in individual self that needs more concern. Values and norms which applied to individuals in school are needed to guide individual behavior (Sarwono, 2012). The manifestation of the application of students values and norms shows to their behavior such as disciplines. Discipline is someone ability to act based on the applicable norms or rules (Sunarti, 2004). Furthermore, discipline is a behavior that reflect obedience, adherence, and orderliness to rules, regulation and valid values in community or society especially in school.

The application of discipline indicates by urge and strong control to individual in channeling their emotion and showing their behavior (McKinney, Brown, \& Malkin, 2018). Individual's discipline can be known by their ability in showing emotion which is not excessive and controlled. Individual with discipline is individual that have an ability to manage and direct themselves as it should be. Foucault (Sandoff \& Widell, 2008) states individual's behavior can be controlled and predicted by discipline. If discipline is well applied, children can build their good character and personality as the society expected them to be that they are part of the society by themselves.

Some factors that affect discipline are differences in race, ethnic, and gender (Wallace et al., 2008), self control (Bergin \& Bergin, 1999; Fachrurrozi, Firman, \& Ibrahim, 2018; Gunawan, 2017; Hiller, 2018; Pujawati, 2016; Widodo, 2013), self openness (Widodo, 2013), parental attention (Bourcier, 2009; Chandra \& Angin, 2017; March, 2018), self adjustment (Gunawan, 2017), parental support (Pujawati, 2016), peer influence, insufficient parenting, difficulty in learning, personal stress, and impaired health (Gitome et al., 2013). Wolhuter \& Steyn (2003) explains that the defining factors in students' discipline problems can be 
categorized into five category including student's factor, teacher's factor, school's factor, parents' factor, and society's factor.

One of factors that affect children's discipline is self control. Every teenager has mechanism in helping them to control and direct their behavior which is self control (Auliya \& Nurwidawati, 2014). Some of them failed in improving their self control that teenagers in their age have in their period of development and it will influence their discipline such as violation of school's rules. Irmim \& Rochim (2004) states one of aspect that builds disciplines is self control. A lot of digression happens due to the absence of self control such as crime and mischievousness (Boman et al., 2019). High self control is needed to ensure diverse in individual's behavior do not happens that they will be directed and discipline.

Teenager with low self control will not be able to guide, direct and manage their behavior. They tend to have inability in controlling the stimulus they faced, inability in considering the possible consequence, and inability in choosing the right action (Widodo, 2013). Baumeister et al., (Daly et al., 2014) mention that insufficient self control contributes to behavior without obstacle and limits the ability to staying on the tasks, chasing the purpose, postponing satisfaction, and following rules which determined socially.

Berk (Widodo, 2013) states individual with self control can avoid negative behavior. On the other hand, those individual who are weak in self controlling tend to do negative behavior or shows undisciplined behavior which are infringe or deviate called as form of problem or breach of discipline. Furthermore, Fiana, Daharnis, \& Ridha (2013) mention that students with good self control can adapt to their environment and avoid self adjustment problems and socialize problem to other individual, also students can obey the school's rules.

The phenomenon in real field shows there are some students that comes late for class, absents, truants, late to collecting the assignments - even they do not do the assignments, comes in and out of class, not neatly dressed, do not do picket based on the schedule, hitting and scribbling tables and also stays outside of the class when there is no teacher around. Those actions happen due to some affecting factors. Due to a lot of discipline cases happens in school, a research as the first step to find out the contribution of self control to students' discipline is needed. Since self controlis included to factor that affect students' discipline.

\section{Method}

This research was a quantitative research with correlation descriptive research. This research described the contribution of self control to students' discipline. The variables of this research were self control (X) and students' discipline (Y) which was dependent variable. The subject of this research was 275 students of SMAN 1 Kampung Dalam. The researcher used Self Control Scale and Students' Discipline Scale to collect the data. SPSS version 20 was used to process the data of self control and students' discipline. Data analysis used statistical descriptive method and simple regression with SPSS version 20.

\section{Results and Discussions}

\section{Data description}

Self control

The data of students' self control can be seen from the following table:

Table 1. Frequency distribution and percentage of self control (X) based on category

\begin{tabular}{ccccc}
\hline Self Control Category & Range of Scores & F & \% \\
\hline Excellent & $\geq 83$ & 41 & 14,91 \\
\hline Good & $67-82$ & 157 & 57,09 \\
\hline Fair & $51-66$ & 77 & 28,00 \\
\hline Poor & $35-50$ & 0 & 0 \\
\hline Very Poor & & $\leq 34$ & 0 & 0 \\
\hline & Total & & 275 & 100 \\
\hline
\end{tabular}

Based on the result of research shows by the table above, the self control of 275 students as respondent of the research shows $41(14,91 \%)$ students have excellent self control, $157(57,09 \%)$ students have good self 
control, $77(28,00 \%)$ students have quite good self control and also there is no students have poor and very poor self control. Overall, students have good self control; however it needs to be improved.

\section{Students' Discipline}

The data of students' discipline can be seen from the following table:

Table 2. Frequency distribution and percentage of students' discipline based on category

\begin{tabular}{|c|c|c|c|}
\hline Students' Discipline Category & Range of Scores & $\mathbf{F}$ & $\%$ \\
\hline Excellent & $\geq 136$ & 113 & 41,09 \\
\hline Good & $110-135$ & 146 & 53,09 \\
\hline Fair & $84-109$ & 16 & 5,82 \\
\hline Poor & $58-83$ & 0 & 0 \\
\hline Very Poor & $\leq 57$ & 0 & 0 \\
\hline Total & & 275 & 100 \\
\hline
\end{tabular}

The result of research on the table above shows the students' discipline. Among 275 students as respondent of research, $113(41,09 \%)$ students have excellent discipline, $146(53,09 \%)$ have good discipline, 16 $(5,82 \%)$ students have quite good discipline, and there is no students have poor and very poor category. It means, students have carry out good discipline to themselves in general even though improvement still needed.

\section{Requirements analysis testing}

Requirements analysis testing to research data was used as a consideration to choose and define the type of data that will be used. Normality testing and linearity testing was used as requirements analysis testing to the research data.

Table 3. Normality testing result of self control $(\mathrm{X})$ and students' discipline $(\mathrm{Y})$

\begin{tabular}{ccccc}
\hline Variable & Asymp. Sig. & Significance & & Information \\
\hline $\mathbf{X}$ & 0,171 & & & Normal \\
\cline { 1 - 3 } & 0,051 & 0,05 & Normal \\
\hline
\end{tabular}

The result shows that both variables have Asymp. Sig. score that are bigger than the significance that have been set before $(0,05)$. Thus, the data is normally distributed. On the other hand, linearity testing was used to find the linear relationship between variables as follows:

Table 4. Linearity testing result of self control (X) and students' discipline (Y)

\begin{tabular}{cccc}
\hline Variable & $\mathbf{F}$ & Significance & Information \\
\hline $\mathbf{X Y}$ & 145,558 & 0,000 & Linear \\
\hline
\end{tabular}

The table 4 shows that variable $\mathrm{X}$ is significance to variable $\mathrm{Y}$ is $0,000<0,05$, thus the data is linear.

\section{Hypothesis testing}

The result of hypothesis testing shows the score of $r$ square $\left(r^{2}\right)$ is 0,348 . This means self control is significantly contribute to students' discipline which is $34,8 \%$. Moreover, the result of simple regression analysis is $\mathrm{t}_{\text {observed }} 12,065$ with $0,000<0,005$ significance score. Thus, self control is contributed to students' discipline.

Table 5. Simple Regression analysis result of self control (X) and students' discipline (Y)

\begin{tabular}{ccc}
\hline Variabel & $\mathbf{R}$ & r Square \\
\hline $\mathbf{X}-\mathbf{Y}$ & 0,590 & 0,348 \\
\hline
\end{tabular}




\section{Discussion}

\section{Self control contribution to students' discipline}

Based on the result of the research, there is a significant contribution of self control to students' discipline which is $34,8 \%$ with significance 0,000 . Thus, self control gives significant impact to students' discipline. This finding is based on data analysis score which $r$ score is 0,590 ; means there is strong relationship between self control and students' discipline. Therefore, the more someone has strong self control, the better their ability in improving and building their discipline behavior.

The result above is supported by research of Widodo (2013) that self control and openness factor gives significant impact to build students' discipline behavior. It indicates that the stronger someone self control, the better their ability in improving and building their discipline behavior. The application of discipline shows by the strong urge and control of individual in channeling emotions and showing behavior (McKinney et al., 2018). Fiana, Daharnis, \& Ridha (2013) found that students with good self control will be able to adapt to their environment, avoid problems in adjustment and problems socializing to others and they also capable in obeying the school's rule.

Teenager with low self control cannot guide, direct, and control their behavior. They tend to have inability in controlling the stimulus they face, inability in considering consequence they might face, also inability in choosing the right act (Widodo, 2013).

Some of teenager failed in improving self control as teenager in their age during development process and it will affect to their disciplined such as misconduct behavior in school. Thus, parents' needs to instill consistency that every action that children do have consequence to ensure their children are controllable and disciplined. If teenager have low self control, they would not be able to guide, direct, and control their behavior (Fachrurrozi et al., 2018; Widodo, 2013). Then, those who are unable to control the stimulus they face and unable to consider the consequence they might face would not be able to choose the right action for certain situation.

Berk (Widodo, 2013) states individual with self control can avoid negative behavior. On the other hand, those individual who are weak in self controlling tend to do negative behavior or shows undisciplined behavior which are infringe or deviate called as form of problem or breach of discipline. Based on the explanation above, it can be concluded that self control contributed to students' discipline. Thus, it is important for students to improve their self control to achieve their discipline behavior.

\section{Conclusions}

Based on the findings of the research, students in general have good self control which means they generally have ability in controlling their action. Moreover, students' discipline in general is good which means they can guide themselves to act like how it supposed to be which based on rules and valid norms. On the other hand, another factor that affect students' discipline are differences in race, ethnic, and gender, openness, parental attention, self adjustment, parental support, peer influence, insufficient parenting, difficulty in learning, personal stress, and impaired health problems. Students' self control need to be increased to avoid them from undisciplined behavior.

\section{References}

Auliya, M., \& Nurwidawati, D. (2014). Hubungan kontrol diri dengan perilaku agresi pada siswa SMA Negeri 1 Padangan Bojonegoro. Character, 2(3), 1-6.

Bergin, C., \& Bergin, D. A. (1999). Classroom discipline that promotes self-control. Journal of Applied Developmental Psychology, 20(2), 189-206. https://doi.org/10.1016/S0193-3973(99)00013-1

Boman, J. H., Mowen, T. J., \& Higgins, G. E. (2019). Social learning, self-control, and offending specialization and versatility among friends. American Journal of Criminal Justice, 44(1), 3-22. https://doi.org/10.1007/s12103-018-9445-7

Bourcier, S. (2009). L'attention positive, élément-clé d'une discipline incitative. Metiers de La Petite Enfance, $155,34-35$.

Chandra, A., \& Angin, A. P. (2017). Hubungan perhatian orang tua dan iklim sekolah dengan disiplin pada siswa SMP N 2 Padang Tualang Kabupaten Langkat. Jurnal Psychomutiara, 1(1), 1-14.

Committee on Psychosocial Aspects of Child and Family Health. (1998). Guidance for effective discipline. American Academy of Pediatrics, 101(4).

Daly, M., Baumeister, R. F., Delaney, L., \& MacLachlan, M. (2014). Self-control and its relation to emotions 
and psychobiology: Evidence from a Day Reconstruction Method study. Journal of Behavioral Medicine, 37(1), 81-93. https://doi.org/10.1007/s10865-012-9470-9

Fachrurrozi, Firman, \& Ibrahim, I. (2018). Hubungan kontrol diri dengan disiplin siswa dalam belajar. Jurnal Neo Konseling, 1(1), 1-6. https://doi.org/10.24036/xxxxxxxxxxx-x-xx

Fiana, F. J., Daharnis, \& Ridha, M. (2013). Disiplin siswa di sekolah dan implikasinya dalam pelayanan bimbingan dan konseling. Jurnal Ilmiah Konseling, 2(April), 26-33.

Gitome, J. W., Katola, M. T., \& Nyabwari, B. G. (2013). Correlation between students' discipline and performance in The Kenya Certificate of Secondary Education. International Journal of Education and Research, 1(8), 1-10.

Gunawan, L. N. (2017). Hubungan antara kontrol diri dan penyesuaian diri dengan kedisiplinan siswa MTs Sulaiman Yasin Samarinda. Psikoborneo, 5(1), 104-117.

Hiller, V. (2018). Self-control and the rise and fall of factory discipline. Journal of Development Economics, 133, 187-200. https://doi.org/10.1016/j.jdeveco.2018.02.004

Irmim, S., \& Rochim, A. (2004). Membangun disiplin diri melalui kecerdasan spiritual dan emosional. Jakarta: Batavia Press.

March, J. G. (2018). Some thoughts on the development of disciplines, with particular attention to behavioral strategy. In Advances in Strategic Management (Vol. 39, pp. 13-21). https://doi.org/10.1108/S0742332220180000039001

McKinney, C., Brown, K., \& Malkin, M. L. (2018). Parenting Style, Discipline, and Parental Psychopathology: Gender Dyadic Interactions in Emerging Adults. Journal of Child and Family Studies, 27(1), 290-301. https://doi.org/10.1007/s10826-017-0865-7

Pujawati, Z. (2016). Hubungan kontrol diri dan dukungan orang tua dan perilaku disiplin pada santri di Pondok Pesantren Darussa'adah Samarinda. Journal Psikologi, 4(2), 227-236. http://ejournal.psikologi.fisip-unmul.ac.id/site/wp-content/uploads/2016/02/Jurnal (02-23-16-06-2508).pdf

Sandoff, M., \& Widell, G. (2008). Coping with discipline: discipline and dilemmas among teachers and warders. International Journal of Sociology and Social Policy, 28(11-12), 458-471. https://doi.org/10.1108/01443330810915189

Sarwono, S. W. (2012). Psikologi remaja. Jakarta: Rajawali Pers.

Sunarti, E. (2004). Mengasuh dengan hati: tantangan yang menyenangkan. Jakarta: Elex Media Komputindo.

Tu'u, T. (2004). Peran disiplin pada perilaku dan prestasi siswa. Jakarta: Grasindo.

Wallace, J. M., Wallace, C. M., \& Bachman, J. G. (2008). Racial, ethnic, and gender differences school discipline in US high school students: 1991-2005. The Negro Educational Review, 59, 1991-2005.

Widodo, B. (2013). Perilaku disiplin siswa ditinjau dari aspek pengendalian diri (self control) dan keterbukaan diri (self disclosure) pada siswa SMK Wonoasri Caruban Kabupaten Madiun. Widya Warta, 1, 140-151.

Wolhuter, C. C., \& Steyn, S. C. (2003). Learner discipline at school: a comparative educational perspective. Journal Koers, 68(4), 521-538. 